\title{
Variable Response of Food Crops to Banded and Broadcast Residual Fertilizer P on an Ultisol ${ }^{1,2}$
}

\author{
Reinaldo Del Valle, Jr., T. W. Scott and M. A. Lugo-López ${ }^{3}$
}

\section{ABSTRACT}

In a sequence of ten crops on a Torres clay, an Ultisol, variable responses to fertilizer P were obtained. Rice and soybeans did not respond to fertilizer P. In three corn crops out of six, and in two field bean crops, there was response to banded fertilizer $\mathbf{P}$ but not to broadcast residual $\mathbf{P}$. In the first corn crop, near maximum yields were obtained with $90 \mathrm{~kg} / \mathrm{ha}$ of banded $P$ and with $359 \mathrm{~kg} / \mathrm{ha}$ of broadcast $\mathrm{P}$. The residual effect of large applications of broadcast P on successive crops was almost nil. In field experiments, soil tests indicated a sharp P drop in the broadcast P treatments after three years, perhaps due to $\mathrm{P}$ fixation.

Organic P mineralization appears to be rather important in the highly weathered soils of the humid tropics. Apparently, P is mineralized more rapidly during, the summer months.

\section{INTRODUCTION}

There are approximately 600 million hectares of deep, well-drained, but relatively infertile acid soils (mostly Oxisols and Ultisols) in the humid tropics which are potentially available, yet mostly uncultivated. These soils are generally deep and permeable, with favorable structure.

Response to fertilizer $\mathrm{P}$ has been obtained at various locations (17). However, under conditions in Puerto Rico, response has been uncertain, varied and somewhat unexpected. There appears to be need of $\mathrm{P}$, according to soil tests, but often crops fail to respond to added P. One of the main limiting factors of these soils is their low inherent fertility. The general objectives of this research were to determine the most effective and economic amounts and methods of application of fertilizer $\mathrm{P}$ with and without lime in relation to cropping systems and management practices. $\mathrm{P}$, after $\mathrm{N}$, is perhaps the most limiting nutrient in tropical soils, but research results are baffling.

This paper reports on the results of experimental work under field conditions conducted from 1970 to 1977 with the specific objective of determining the amounts and placement of fertilizer $\mathrm{P}$ required for

${ }^{1}$ Manuscript submitted to Editorial Board September 19, 1978.

${ }^{2}$ Joint contribution from the Department of Agronomy, Cornell University, Ithaca, N. Y., and the Agricultural Experiment Station, University of Puerto Rico, Mayagüez Campus, Río Piedras, P.R. This study was part of investigations supported by U.S. AID under research contract ta-c-1104.

${ }^{3}$ Assistant Agronomist, Agricultural Experiment Station, University of Puerto Rico, Río Piedras, P.R., Professor of Soil Science, Cornell University, Ithaca, N. Y., and Professor and Soil Scientist (Ret.), Agricultural Experiment Station, University of Puerto Rico. Appreciation is expressed to Drs. Richard H. Fox, Frederick Beinroth and Jaime Jordan Molero for their help in the initial stages of the work herein reported. 
optimum production, to evaluate long-term and residual effects of fertilizer $\mathrm{P}$ on crop yields and to relate soil properties to fertilizer $\mathrm{P}$ requirements and crop response.

\section{PREVIOUS WORK}

Considerable work has been done in Puerto Rico related to the possible response of various crops to $\mathrm{P}$ applications. Samuels and Capó (20) in a review of all the fertilizer work with sugarcane conducted between 1910 and 1954, report none to little response to $\mathrm{P}$ even though applications were as high as $197 \mathrm{~kg} / \mathrm{ha}$. When $\mathrm{P}$ was omitted from the fertilizer treatments, decreases in yield were only $7 \%$. However, some soils showed a need for $\mathrm{P}$ for higher cane yields: Fajardo clay loam (Alfisol), Coto clay (Oxisol) and Vega Baja silty clay (Ultisol). In addition, $\mathrm{P}$ fertilizer placement studies revealed no significant differences in yield attributable to method of placement. Data from Bonnet (9), on 18 consecutive sugarcane crops in a Vega Alta clay soil (Ultisol) between 1943-63, failed to reveal response to $\mathrm{P}$ rates as low as 10 and $39 \mathrm{~kg} / \mathrm{ha}$ in terms of tons of cane/ha, sucrose percent cane and tons of sugar/ha.

The response of pineapple to $\mathrm{P}$ applications has been variable. Samuels et al. (21), studying the influence of P fertilizers in a Lares clay (Ultisol) and a Bayamón sandy loam (Oxisol) failed to obtain, in general, significant yield increases. Samuels (22), in a review of the fertilizer research with this crop in the island from 1955-66, concluded that yield response to $\mathrm{P}$ had been very limited and observed that significant depressions in yields were obtained when rates of $\mathrm{P}$ exceeded $28 \mathrm{~kg} / \mathrm{ha}$. Various $\mathrm{P}$ sources did not increase yields. More recent work with the newly developed cultivar PR 1-67, in a Bayamón sandy loam (Oxisol) at Manatí, revealed that the highest fruit yield (27 tons/ha) was obtained with an application of 24 $\mathrm{kg} / \mathrm{ha}$ of fertilizer $\mathrm{P}$. The highest application $(144 \mathrm{~kg} / \mathrm{ha})$ produced the lowest yields although differences were not significant (12). Similarly, in another experiment with the same cultivar in 1977, in the same soil type, a maximum yield of $28 \mathrm{~T} / \mathrm{ha}$ was obtained with an application of $25 \mathrm{~kg}$ / ha of $\mathrm{P}$ while the lowest $(23.4 \mathrm{t} / \mathrm{ha})$ was obtained with an application of $148 \mathrm{Kg} / \mathrm{ha}$ of P. Mean annual production in Puerto Rico for the past 20 years has been $14 \mathrm{~T} / \mathrm{ha}(13)$.

No significant effects due to $\mathrm{P}$ applications have been observed with old limed coffee trees nor with intensively managed sun grown coffee trees in an Alonso clay (Ultisol) at Castañer (3, 4, 8). However, some moderate response from experiments at Castañer in 1943-44 (1) and at Maricao with cv Columnaris in 1954-55 (14) both in a Catalina clay (Ultisol), have been reported.

Results from $\mathrm{P}$ applications to crops of rather short life cycles show variable to no response. In general, sweet potatoes do not respond to $\mathrm{P}$ 
applications in different soils of Puerto Rico (1, 7, 11, 18). Muñiz (19), working with sweet corn in two different soils, namely a Coto clay (Oxisol) at Isabela and a Fraternidad clay (Vertisol) at Lajas, did not observe differences between treatments attributable to $\mathrm{P}$ applications. No detrimental effects to plants due to the high rates of this element were observed. Similarly Spain (23) in the same Oxisol at Isabela did not find response to $\mathrm{P}$ and micronutrient application to sweet corn. However, response from vegetable crops and grasses has been reported. Spain (24), conducting NPK experiments with cantaloupe and cucumbers in Isabela (Coto clay), obtained significant yield responses over the control with 296 $\mathrm{kg} / \mathrm{ha}$ of fertilizer P. Watermelons and snapbeans responded to applications of $49 \mathrm{~kg} / \mathrm{ha}$ of fertilizer P. Increased yields of pumpkins cv Borinquen were obtained in an NPK experiment on a Fraternidad clay (Vertisol) at Lajas in 1976-77, with low applications of 48 and $97 \mathrm{~kg} / \mathrm{ha}$ of $\mathrm{P}$ (12).

Abruña and Figarella (2), studying the effects of calcium carbonate and $\mathrm{P}$ applications on the yield of a tropical Kudzu pasture in an Oxisol (Catalina clay), observed that lime alone, or in combination with $22 \mathrm{~kg}$ / ha of $\mathrm{P}$, increased yields significantly. Figarella et al. (15) also obtained strong responses in yield from Napier grass with yearly $\mathrm{P}$ applications of $74 \mathrm{~kg} / \mathrm{ha}$ of $\mathrm{P}$ on Catalina and Múcara (Inceptisol) soils. No response, however, was obtained over a 5-year period with Napier, Guinea and Pangola grasses when grown in a Fajardo clay (Alfisol) which had been under well fertilized sugarcane for many years.

A very large response to added $\mathrm{P}$ was obtained from a corn experiment with 3 low-P soils (Ultisols and an Oxisol) in open-bottom sunken drums (16). Nipe clay, considered a rather unproductive, highly weathered Oxisol, gave as high corn yields as the more productive soils (Los Guineos and Humatas clay) when P was added. Available soil P, as measured by the Bray No. 2 (dilute acid soluble P) extraction procedure, was apparently a reliable indicator of $\mathrm{P}$ response in these sunken drum experiments. In a set of experiments under field conditions on a Humatas clay (Ultisol) at Corozal (5), no response to banded and broadcast $\mathrm{P}$ was obtained. In an $\mathrm{N}$ and $\mathrm{P}$ experiment with plantains at the same site at Corozal, bunch and fruit weights increased with increments of $\mathrm{P}$ fertilizer from 0 to 56 $\mathrm{kg} / \mathrm{ha}$ applied at planting or with $179 \mathrm{~kg} / \mathrm{ha}$ of residual P. Lack of $\mathrm{P}$ reduced weight and pulp content in the fingers of the third hand. Over 300,000 fruits/ha were harvested from two successtive crops (10).

\section{MATERIALS AND METHODS}

Due to the low and variable response to $\mathrm{P}$ at the Humatas site indicated previously, an intensive search was made for a low $\mathrm{P}$ soil where additional field experiments could be conducted. A site was finally selected on a 
private farm near Cidra, Puerto Rico. The soil is a Torres clay, Orthoxic Palehumults, clayey, oxidic, isohyperthermic. Selected chemical properties of this soil are listed in table 1. The Bray No. 2 extractable P content averaged $5.5 \mathrm{p} / \mathrm{m}$ in the topsoil. Similar soils with approximately the same $\mathrm{P}$ content had given marked responses to $\mathrm{P}$ under greenhouse conditions.

A corn experiment was planted at this site October 1971. From there on, a series of 10 successive experiments with various test crops (mostly corn) were conducted. The identity of the plots was maintained throughout the crop sequence. The objectives of these studies were to define response curves for $\mathrm{P}$ fertilizers; to measure the relative efficiency of

TABLE 1.-Selected chemical properties of Torres clay

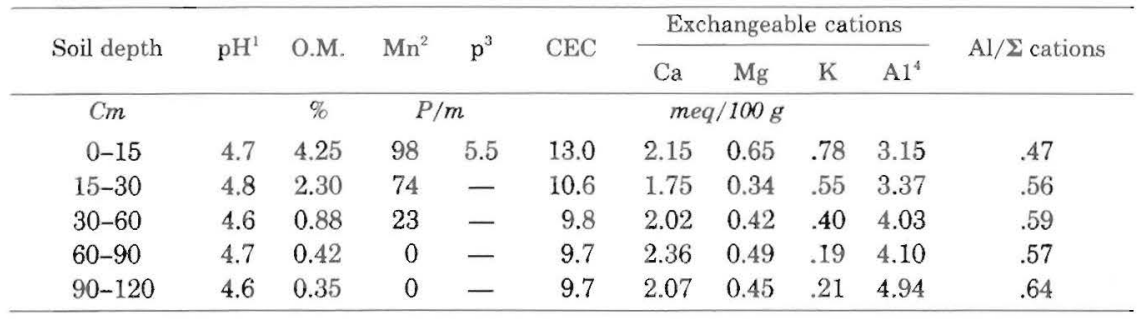

${ }^{1} \mathrm{H}_{2} \mathrm{O}$ : soil ratio of $2: 1$.

${ }^{2} \mathrm{CEC}, \mathrm{Ca}, \mathrm{Mg}, \mathrm{Mn}$ and $\mathrm{K}$ determined with a $\mathrm{NH}_{4} \mathrm{OAc}(\mathrm{pH} 7.0$ ) extracting solution.

${ }^{3}$ Bray No. 2.

${ }^{4}$ Equilibrium concentration $10 \mathrm{~g}$ soil: $100 \mathrm{ml} 1 \mathrm{~N} \mathrm{KCl}$.

banded $\mathrm{P}$ vs. broadcast $\mathrm{P}$ and a combination of both; and to estimate the residual effect of broadcast $P$.

A randomized block design was used with 11 treatments and 5 replications. Treatments were one application of $90,179,359$ or $1120 \mathrm{~kg} / \mathrm{ha}$ of broadcast plow-down $\mathrm{P}$ and one application of $22,45,90$ or $179 \mathrm{~kg} / \mathrm{ha}$ of banded $\mathrm{P}$ for each crop. Also included were a check treatment receiving no $\mathrm{P}$, a treatment consisting of an initial application of $359 \mathrm{~kg} / \mathrm{ha}$ broadcast $\mathrm{P}$ plus $22 \mathrm{~kg} / \mathrm{ha}$ banded $\mathrm{P}$ applied to each crop, and a no-lime treatment receiving $1120 \mathrm{~kg} / \mathrm{ha}$ of broadcast P. Limestone, at a rate of 7.8 metric tons/ha, was plowed under in all plots, except in the no-lime treatment, before planting the first crop. An additional application of 9 tons/ha was made in 1972 after harvesting the first crop. Table 2 shows the crop sequence and blanket applications for the 10 experiments. A carefully planned pest control program was carried out for all the crops.

Plots were $4.7 \times 9.4 \mathrm{~m}$ with an area of $.025 \mathrm{ha}$. Each plot consisted of 6 rows planted $76 \mathrm{~cm}$ apart for a population of 48,000 plants/ha. 


\section{RESULTS AND DISCUSSION}

\section{FIRST CROP: CORN, PIONEER X-306}

Typical symptoms of $\mathrm{P}$ deficiency were observed in the zero and low $\mathrm{P}$ treatment plots within 1 week after seedling emergence. Height differences became evident two weeks after emergence and persisted throughout the growth of the crop.

TABLE 2.-Crop sequence and blanket fertilizer applications at the Cidra experimental field (Torres clay)

\begin{tabular}{|c|c|c|c|c|c|c|}
\hline $\begin{array}{l}\text { Experiment } \\
\text { No. }\end{array}$ & Crop & $\mathrm{N}$ & $\mathrm{K}_{2} \mathrm{O}^{5}$ & $\mathrm{Mg}^{6}$ & $\operatorname{Lime}^{7}$ & $\mathrm{Zn}^{8}$ \\
\hline & & & $K g / h a$ & & $\begin{array}{l}\text { Metric } \\
\text { T/ha }\end{array}$ & $\mathrm{Kg} / \mathrm{ha}$ \\
\hline 1 & Corn, Pioneer X-306 & $\begin{array}{r}112^{1} \\
67^{2} \\
56^{3}\end{array}$ & 168 & 56 & 7.8 & 0 \\
\hline 2 & Corn, Pioneer X-306 & $\begin{array}{r}112^{2} \\
56^{1}\end{array}$ & 56 & 112 & 9.0 & 0 \\
\hline 3 & Rice, Sinaloa & $80^{4}$ & 112 & 56 & 0 & 0 \\
\hline 4 & Soybeans, Hardee & $\overline{42^{1}}$ & 224 & 56 & 0 & 0 \\
\hline 5 & Corn, Funk's G-795 W & $126^{4}$ & 100 & 75 & 0 & 0 \\
\hline 6 & Corn, Funk's G-795 W & $150^{4}$ & 75 & 50 & 0 & 0 \\
\hline 7 & Corn, Pioneer X-306 B & $\begin{array}{r}150^{4} \\
38^{3}\end{array}$ & 75 & 50 & 0 & 0 \\
\hline 8 & Corn, Pioneer X-306 B & $113^{2}$ & 75 & 50 & 0 & 0 \\
\hline 9 & Fieldbeans, Bonita & $112^{2}$ & 112 & 50 & 0 & 0 \\
\hline 10 & Fieldbeans, Bonita & $112^{2}$ & 112 & 50 & 0 & 0 \\
\hline
\end{tabular}

${ }^{1}$ Preplant urea.

${ }^{2}$ Postplant sidedress ammonium sulphate.

${ }^{3}$ Preplant ammonium sulphate.

${ }^{4}$ Postplant, sidedress, urea.

${ }^{5}$ As sulphate.

${ }^{6}$ As sulphate.

${ }^{7}$ As limestone.

${ }^{8}$ As sulphate.

The banded $\mathrm{P}$ applications were more effective than the broadcast applications. Near maximum growth was obtained with $90 \mathrm{~kg} / \mathrm{ha}$ of banded P, whereas $359 \mathrm{~kg} / \mathrm{ha}$ of broadcast P were necessary for near maximum growth (fig. 1). A statistical regression between plant height and applied $\mathrm{P}$ revealed that the use of the Mitscherlich equation resulted in very high coefficients of determination. For banded $P,(0-179 \mathrm{~kg} / \mathrm{ha}) r^{2}$ was 0.97 ; for broadcast $\mathrm{P},(0-1120 \mathrm{~kg} / \mathrm{ha}), 0.99$. The omission of lime did not affect plant height.

The higher $\mathrm{P}$ treatments began to tassel before the check and low $\mathrm{P}$ 
plots. The low $\mathrm{P}$ plots continued growing until they tasseled with the result that height differences among treatments were less after all plants had tasseled. When the corn ears were still young (95 days after planting and about 30 days before normal maturity), a relatively unknown disease, Phyllacora maydis (tar spot), attacked the corn and caused premature leaf death, grain yield reduction, and yield variability.

The response curves for grain yield versus P applied (fig. 2) were very similar to those comparing plant height with applied P (fig. 1). Banded P was much more effective than broadcast $\mathrm{P}$ in increasing grain yield. Soil

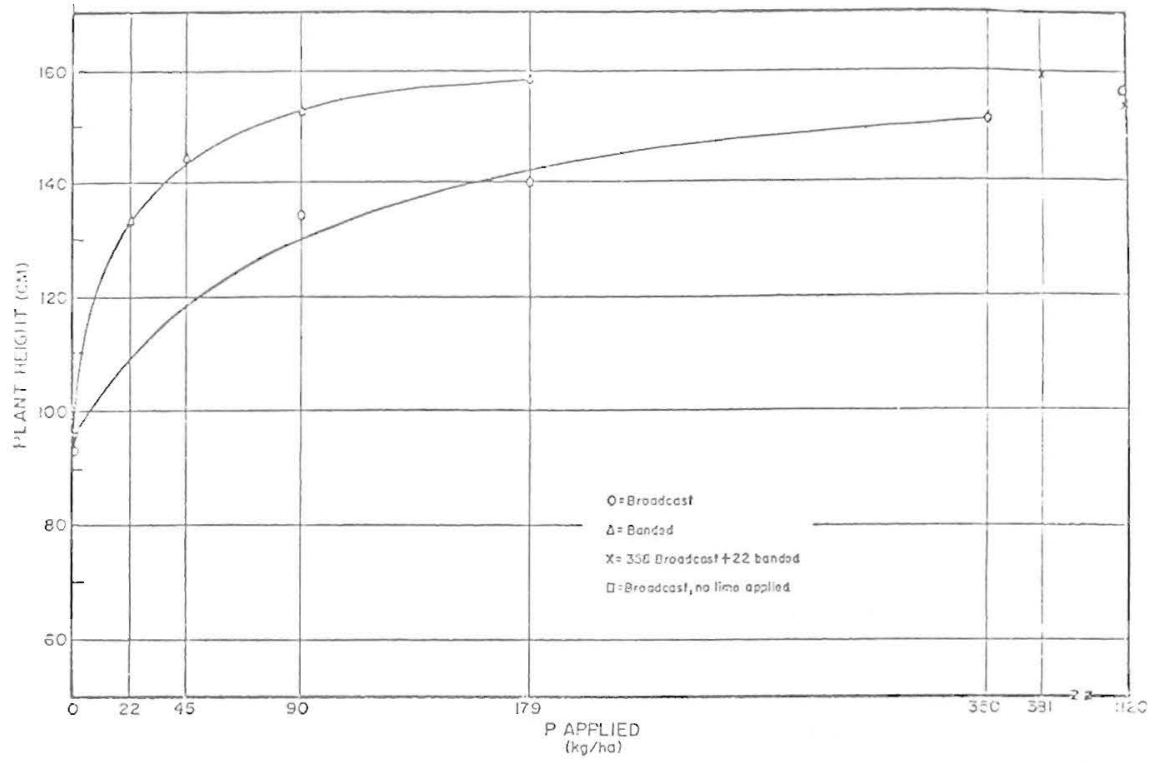

FIG. 1.-Response of corn plant height 61 days after planting to applications of $\mathrm{P}$ to Torres clay, winter 71-72.

analyses for $\mathrm{P}$ from samples taken after harvest at $0-15 \mathrm{~cm}$ in treatments 1-6 (table 3), revealed that the Bray No. 2 extractable P contents were, as averages, $6.0,9.5,24.4,32.8$ and $172 \mathrm{p} / \mathrm{m}$ in treatments receiving 0,90 , 179,359 and $1120 \mathrm{~kg} / \mathrm{ha}$, respectively, of broadcast P. In Alabama, it has been observed that there is generally no response when Bray No. 2 levels are higher than $20 \mathrm{p} / \mathrm{m}$ and that there is a marked response at $5-8 \mathrm{p} / \mathrm{m}$. ${ }^{4}$

Perhaps crop response to $\mathrm{P}$ in this soil was not greater because of mineralization of organic $\mathrm{P}$. The soil contains a relatively high organic matter content $(4.25 \%)$ and in an adjacent experiment, enough $\mathrm{N}$ was mineralized to result in no response to fertilizer $\mathrm{N}$ in two successive corn crops.

${ }^{4}$ R. W. Pearson. Personal communication, Auburn University, Auburn, Alabama, 1975. 
SECOND CROP: CORN, PIONEER X-306

Differences in early growth due to P treatments were again observed, but the differences were not as marked as in the first crop. Height differences in the later stages of growth were also less marked than in the first crop (fig. 3). At maturity, plant height was less than normal for the hybrid used probably due to a severe drought during the growing season.

The smaller, slower growing, P-deficient plants would presumably transpire less water, and would continue to grow until they, too, were limited by lack of soil-water. In support of this hypothesis it was observed

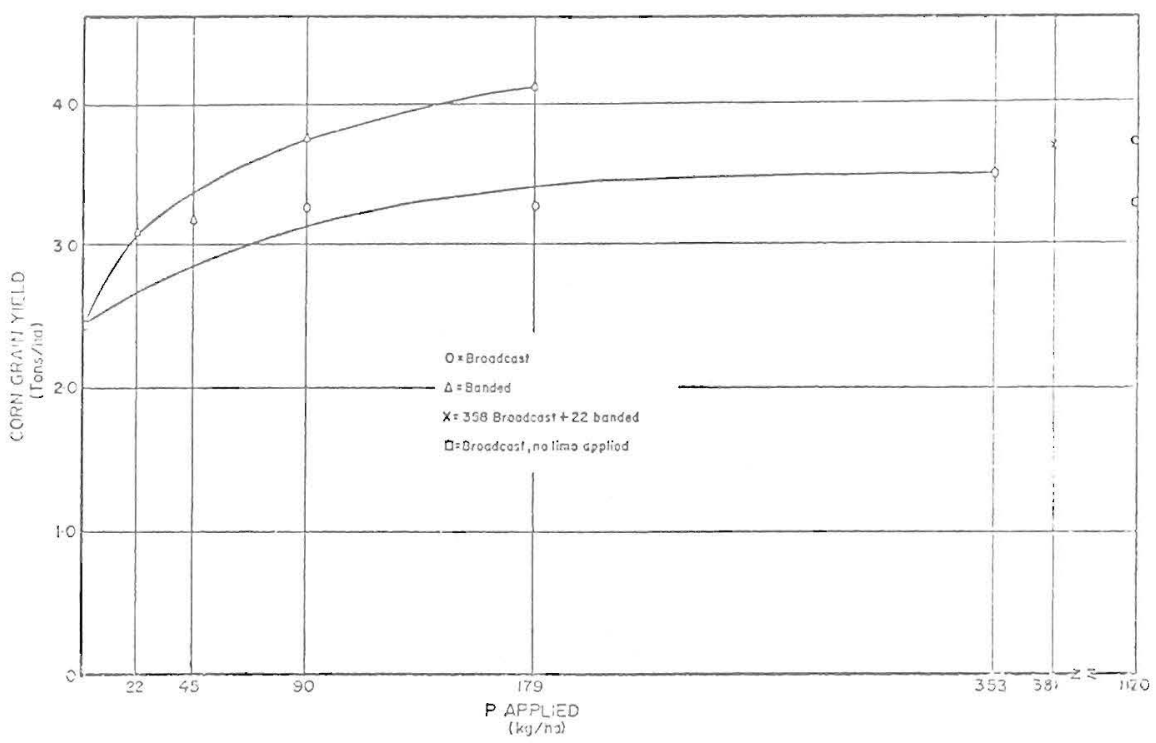

Frg. 2.- Response of corn grain yield to applications of $\mathrm{P}$ to Torres clay, winter 71-72.

that 11 days before the second set of height measurements were taken the larger plants were wilting, while the smaller low-P treatment plants were not. Grain yields were approximately $900 \mathrm{~kg} / \mathrm{ha}$ lower and considerably more variable than those of an adjacent $\mathrm{N}$ experiment which was planted at the same time and, except for fertilizer, received the same management. The difference in management was that the $\mathrm{P}$ experiment received a total of $169 \mathrm{~kg} / \mathrm{ha}$ of $\mathrm{N}$ split in applications of $56 \mathrm{~kg}$ of urea pre-plant $+112 \mathrm{~kg} / \mathrm{ha}$ of ammonium sulphate, whereas all the fertilizer $\mathrm{N}$ in the $\mathrm{N}$ experiment was in the form of urea.

The highest grain yield $(5,797 \mathrm{~kg} / \mathrm{ha})$ was obtained from the limed treatment which received no $\mathrm{P}$; the lowest, from the treatment which received $1,120 \mathrm{~kg} / \mathrm{ha}$ of $\mathrm{P}+$ lime (table 4 ). This negative response to $\mathrm{P}$ 


\begin{tabular}{|c|c|c|c|c|c|c|c|c|c|c|c|}
\hline $\begin{array}{l}\text { Treatment } \\
\text { No. }\end{array}$ & $\begin{array}{c}\mathrm{P}(\mathrm{Kg} / \mathrm{ha}) \\
\text { Broadcast } 1971\end{array}$ & $\begin{array}{l}\text { March } \\
1972\end{array}$ & $\begin{array}{l}\text { Sept. } \\
1972\end{array}$ & $\begin{array}{l}\text { April } \\
1973\end{array}$ & $\begin{array}{l}\text { Sept. } \\
1973\end{array}$ & $\begin{array}{l}\text { April } \\
1974\end{array}$ & $\begin{array}{l}\text { Sept. } \\
1974\end{array}$ & $\begin{array}{l}\text { Febr. } \\
1975\end{array}$ & $\begin{array}{l}\text { Dec. } \\
1975\end{array}$ & $\begin{array}{l}\text { Aug. } \\
1976\end{array}$ & $\begin{array}{l}\text { Oct. } \\
1977\end{array}$ \\
\hline 1 & 0 & 6.0 & 6.6 & 13.4 & 7.0 & 10.4 & 3.5 & 2.2 & 9.9 & 8.9 & 4.6 \\
\hline 2 & 90 & 9.5 & 9.41 & 12.3 & 7.0 & 16.0 & 5.0 & 2.6 & 8.2 & 5.3 & 2.8 \\
\hline 3 & 179 & 24.4 & 12.7 & 12.9 & 11.0 & 13.4 & 4.4 & 2.4 & 9.9 & 9.0 & 5.9 \\
\hline 4 & 359 & 32.8 & 17.6 & 21.4 & 12.0 & 12.5 & 4.7 & 2.5 & 9.6 & 7.8 & 6.2 \\
\hline 5 & $1120^{1}$ & 172.0 & 66.1 & 95.5 & 57.0 & 12.3 & 15.7 & 10.4 & 23.3 & 21.9 & 13.7 \\
\hline 6 & 1120 & 15.2 & 108.5 & 86.0 & 55.0 & 9.8 & 18.6 & 11.8 & 24.2 & 19.5 & 13.8 \\
\hline
\end{tabular}

\footnotetext{
${ }^{1}$ All treatments received $\mathrm{CaCO}_{3}$ except No. 5 .
} 
registered only in the case of grain yield and weight and might be attributed to high levels of available P in the soil. Stover yield was generally higher with higher rates of banded P. As a matter of fact, there was a negative correlation between grain yield and stover yield ( $r=$ -0.57 ). This suggested that the lower grain yields in the high $\mathrm{P}$ treatments may have resulted from greater use of soil-water by the relatively larger plants in the early stages of growth with subsequent greater water stress during silking, and a consequent reduction in grain yield. This was substantiated by the observation, 32 days after planting, that the larger $\mathrm{P}$-fertilizer plants were wilting and the smaller-P deficient plants were not.

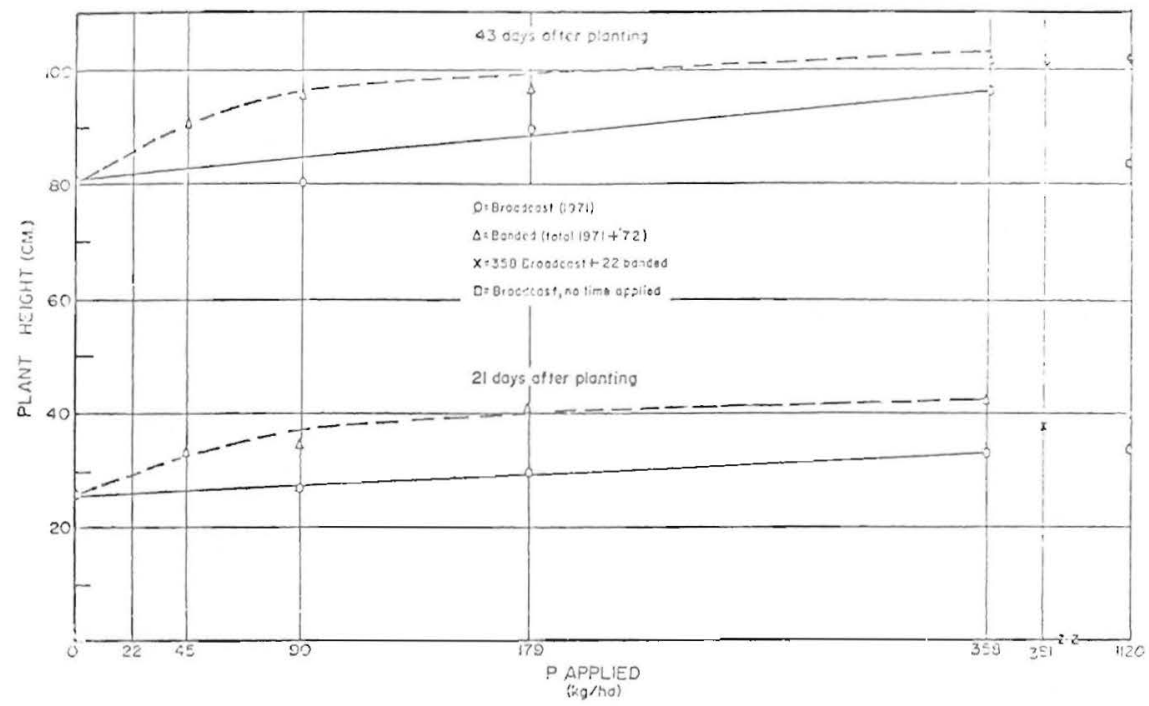

FIG. 3.-Response of corn plant height to applications of $P$ to Torres clay, summer 1972.

The most remarkable result from this experiment was that the zero $\mathrm{P}$ treatment yielded $5,797 \mathrm{~kg} / \mathrm{ha}$ (92 bu/acre) of grain when there were only $0.0027 \mathrm{p} / \mathrm{m}$ of $\mathrm{P}$ in the soil solution and $6.6 \mathrm{p} / \mathrm{m}$ of Bray No. 2 extractable $\mathrm{P}$ (table 3), both far below levels considered adequate for near maximum yields. Evidently, there was enough mineralization or organic $\mathrm{P}$ to supply plant needs once their root systems had become extensive enough to utilize the immobile mineralized $\mathrm{P}$. This hypothesis was supported by the estimate that at least $278 \mathrm{~kg} / \mathrm{ha}$ of $\mathrm{N}$ were mineralized for the last two crops in the adjacent $\mathrm{N}$ experiment. Pioneer X-306 might be capable of producing fairly good yields at low P levels.

The unlimed treatment produced the smallest grain yield. This was probably due to $\mathrm{Al}$ or $\mathrm{Mn}$ toxicity, as the average soil $\mathrm{pH}$ in this treatment 
was 4.28 after harvest. Analysis of leaf tissue at silking showed that the leaves from plants in this treatment contained toxic levels of Mn (893 p/ $\mathrm{m}$ when over $200 \mathrm{p} / \mathrm{m}$ are considered toxic).

The Bray No. 2 extractable P content after harvest (table 3) in the limed treatments which received banded $\mathrm{P}$ at rates of 179 and $359 \mathrm{~kg} / \mathrm{ha}$ and $1120 \mathrm{~kg} / \mathrm{ha}$ of broadcast $\mathrm{P}$ in the fall of 1971 was about half of that measured in April 1972. The P content in the soil from treatments 0 and $90 \mathrm{~kg} / \mathrm{ha}$ changed only slightly.

\section{THIRD CROP: RICE, SINALOA}

A rice crop, cultivar Sinaloa, introduced from Mexico, was planted October 6, 1973, (replanted November 6) at a rate of $67 \mathrm{~kg} /$ ha with an interrow distance of $20 \mathrm{~cm}$. In this case, the banded $\mathrm{P}$ treatments were omitted. Leaf samples were taken in January 15, 1973, 3.3 months after planting. The third fully developed leaf was taken from a subplot area of $3.05 \times 3.05 \mathrm{~m}$. The experiment was harvested April 12, 1973, 188 days after sowing. An area of $2 \mathrm{~m}^{2}$ was selected from the subplots for yield calculations.

Less than a month after planting, all plots showed a leaf chlorosis which was more evident in the high $\mathrm{P}$, unlimed treatments. These symptoms could have been caused by a Mn-induced Fe deficiency. Results from leaf analyses revealed high concentrations of $\mathrm{Mn}$ in the leaves (table 5). Even though the literature available on rice states that $\mathrm{Mn}$ is required in high quantities for normal growth of the rice plant, an Fe:Mn ratio of $1: 21$ was observed in the $1120 \mathrm{~kg} / \mathrm{ha} \mathrm{P}$ unlimed plots. An Fe:Mn ratio of 1:5 is considered within the sufficiency ranges by Westfall ${ }^{5}$ at panicle initiation. All plots had Fe:Mn ratios higher than the sufficiency levels.

A tip dieback disease, known as leaf scald and caused by Rhyncosporium oryzae, was detected 1 month after planting. The tips of the leaves appeared to be dried or dying out. The dryness continued as the plant aged, extending towards the middle section of the leaf blade, and causing a change in leaf color from green to light brown. Abscission of green immature grains was also observed at heading and grain filling.

There was no response to $\mathrm{P}$ applications. Grain yields were quite variable (table 4) probably due to disease and nutrient deficiencies. A mean grain yield of $1,521 \mathrm{~kg} / \mathrm{ha}$ was obtained. This was considered as a very poor yield for this variety, which is capable of producing over 6,000 $\mathrm{kg} / \mathrm{ha}$ when planted in October under irrigation. ${ }^{6}$

${ }^{5}$ D. G. Westfall, Tissue analysis of Rice, Texas A \& M Univ. and Agric. Exp. Stn. Prog, Rep. 3099, pp. 24-28, 1972.

${ }^{6} \mathrm{~J}$. Vicente-Chandler, Personal communication, 1971. 
TABLE 4.-Yield results of 8 consecutive crops grown on an Ultisol (Torres clay) at Cidra, Puerto Rico between $1971-1976$

\begin{tabular}{|c|c|c|c|c|c|c|c|c|c|c|c|}
\hline $\begin{array}{c}\text { Treatment } \\
\text { No. }\end{array}$ & Lime & $\begin{array}{c}\text { P Broadcast } \\
(1971) \\
\text { Residual }\end{array}$ & $\begin{array}{c}\mathrm{P}(\mathrm{Kg} / \mathrm{ha}) \\
\text { Banded }^{2}\end{array}$ & $\begin{array}{c}\text { Corn } \\
1971-72\end{array}$ & $\begin{array}{l}\text { Corn } \\
1972\end{array}$ & $\begin{array}{c}\text { Rice } \\
1972-73\end{array}$ & $\begin{array}{c}\text { Soybean }^{4} \\
1973\end{array}$ & $\begin{array}{c}\text { Corn } \\
1973-74\end{array}$ & $\begin{array}{l}\text { Corn }^{5} \\
1974\end{array}$ & $\begin{array}{l}\text { Corn } \\
1975\end{array}$ & $\begin{array}{c}\text { Dry Beans } \\
1975-76\end{array}$ \\
\hline 1 & 0 & 1120 & 0 & $3277^{\mathrm{ab} 3}$ & $3807^{\mathrm{b}}$ & 1447 & 3573 & $3578^{\mathrm{abc}}$ & $2753^{\text {abc }}$ & $2997^{\mathrm{b}}$ & $1182^{c}$ \\
\hline 2 & 16.8 Ton/ha, $1971^{1}$ & 0 & 0 & $2423^{\mathrm{a}}$ & $5797^{\mathrm{a}}$ & 1733 & 3680 & $3139^{a b}$ & $2482^{c}$ & $3629^{b}$ & $1489^{\mathrm{abc}}$ \\
\hline 3 & 16.8 Ton/ha, $1971^{1}$ & 90 & 0 & $3236^{b}$ & $4930^{\mathrm{ab}}$ & 1541 & 3311 & $2938^{a}$ & $2683^{a b c}$ & $3891^{\mathrm{ab}}$ & $1229^{\mathrm{bc}}$ \\
\hline 4 & 16.8 Ton/ha, $1971^{1}$ & 179 & 0 & $3261^{b}$ & $5149^{\mathrm{ab}}$ & 1506 & 3577 & $3585^{\mathrm{abc}}$ & $2476^{\mathrm{bc}}$ & $2429^{b}$ & $1121^{\mathrm{c}}$ \\
\hline 5 & 16.8 Ton/ha, $1971^{1}$ & 359 & 0 & $3459^{\mathrm{b} 1}$ & $4198^{\mathrm{ab}}$ & 1452 & 3645 & $4011^{\text {abe }}$ & $3404^{\mathrm{abc}}$ & $3061^{\mathrm{b}}$ & $1229^{\mathrm{bc}}$ \\
\hline 6 & 16.8 Ton/ha, $1971^{1}$ & 1120 & 0 & $3701^{\text {be }}$ & $4447^{\mathrm{ab}}$ & 1510 & 4378 & $4206^{b c}$ & $3519^{\mathrm{ab}}$ & $3524^{\mathrm{b}}$ & $1653^{a b}$ \\
\hline 7 & 16.8 Ton/ha, $1971^{1}$ & 0 & 22 & $3190^{\mathrm{b}}$ & $4982^{a b}$ & 1317 & 3475 & $3861^{\text {abc }}$ & $3021^{\mathrm{abc}}$ & $4679^{a}$ & $1854^{\mathrm{a}}$ \\
\hline 8 & 16.8 Ton/ha, $1971^{1}$ & 0 & 45 & $3195^{\mathrm{b}}$ & $5234^{\mathrm{ab}}$ & 1775 & 3830 & $4049^{a b c}$ & $3319^{a b}$ & $3789^{\mathrm{ab}}$ & $1754^{a}$ \\
\hline 9 & 16.8 Ton/ha, $1971^{1}$ & 0 & 90 & $3792^{\text {be }}$ & $4658^{a b}$ & 1483 & 3499 & $4539^{c}$ & $3080^{\mathrm{abc}}$ & $3663^{\mathrm{b}}$ & $1536^{\mathrm{abc}}$ \\
\hline 10 & 16.8 Ton/ha, $1971^{1}$ & 0 & 179 & $4135^{\mathrm{c}}$ & $4583^{\mathrm{ab}}$ & 1521 & 4229 & $5813^{d}$ & $3839^{\mathrm{a}}$ & $3903^{\mathrm{ab}}$ & $1667^{\mathrm{ab}}$ \\
\hline
\end{tabular}

${ }^{1}$ A total of 16.8 metric tons/ha (7 1/2 tons/acre) of ground $\mathrm{CaCO}_{3}$ had been applied prior to planting the soybean experiment; 7.8 tons before planting the first corn crop (1971); and 9 tons after harvesting the first corn experiment (1972).

${ }^{2}$ Applied to each crop, except rice.

${ }^{3}$ Values followed by one or more letters in common do not differ significantly at the $5 \%$ probability level using Duncan's Multiple Range Test.

${ }^{4}$ Results published, J. Agri. Univ. P.R. 61H(2): 179-6, 1977.

${ }^{5}$ The seventh crop with corn was lost. 
Soil analyses revealed that the high $\mathrm{P}$ unlimed treatment had a $\mathrm{pH}$ of 3.8 with an extractable A1 content of $2.75 \mathrm{meq} / 100 \mathrm{~g}$ of soil, while the A1 content for the other treatments was practically nil. The values of Bray No. 2 extractable $P$ in the limed treatments were generally higher than those measured after the second crop.

FOURTH CROP: SOYBEANS, HARDEE

A soybean, Glycine $\max$ (L.) Merill, crop was planted June 29, 1973. Seeds of cultivar Hardee were sown at a rate of $100 \mathrm{~kg} / \mathrm{ha}$ in rows $46 \mathrm{~cm}$

TABLE 5.-Leaf nutrient composition of rice plants variety Sinaloa at 3.3 months after planting, Cidra

\begin{tabular}{|c|c|c|c|c|c|c|c|c|c|c|c|}
\hline \multirow{2}{*}{$\begin{array}{c}\text { Treatment } \\
\text { No. }\end{array}$} & \multirow{2}{*}{ Lime } & \multicolumn{2}{|l|}{$P$} & \multicolumn{8}{|c|}{ Content of indicated element } \\
\hline & & $\begin{array}{c}\text { Broadcast, } \\
1971\end{array}$ & $\begin{array}{l}\text { Banded } \\
\text { each yr. }\end{array}$ & $\mathrm{N}$ & $\mathrm{P}$ & $\mathrm{K}$ & $\mathrm{Ca}$ & $\mathrm{Mg}$ & $\mathrm{Fe}$ & $\mathrm{Mn}$ & $\mathrm{Zn}$ \\
\hline & & \multicolumn{2}{|c|}{$K g / h a$} & \multicolumn{4}{|c|}{$\%$} & & \multicolumn{3}{|c|}{$P / m$} \\
\hline $1^{1}$ & 0 & 1121 & 0 & 3.48 & .37 & 1.57 & .68 & .60 & 103 & 2200 & 21 \\
\hline 2 & To $\mathrm{pH} 5.5-6.0$ & 0 & 0 & 3.59 & .31 & 1.59 & .76 & .35 & 140 & 1050 & 26 \\
\hline 3 & To $\mathrm{pH}$ 5.5-6.0 & 90 & 0 & 3.73 & .26 & 1.77 & .52 & .32 & 95 & 1000 & 19 \\
\hline 4 & To $\mathrm{pH}$ 5.5-6.0 & 179 & 0 & 3.60 & .28 & 1.80 & .71 & .47 & 121 & 1225 & 20 \\
\hline 5 & To $\mathrm{pH}$ 5.5-6.0 & 359 & 0 & 3.71 & .22 & 1.50 & .53 & .26 & 84 & 710 & 14 \\
\hline 6 & To $\mathrm{pH} 5.5-6.0$ & $112 \mathrm{I}$ & 0 & 3.60 & .33 & 1.75 & .68 & .47 & 101 & 1295 & 19 \\
\hline 7 & To $\mathrm{pH} 5.5-6.0$ & 0 & 22 & 3.66 & .27 & 2.07 & .69 & .50 & 105 & 1145 & 22 \\
\hline 8 & To $\mathrm{pH} 5.5-6.0$ & 0 & 45 & 3.71 & .19 & 1.28 & .37 & .19 & 72 & 812 & 16 \\
\hline 9 & To $\mathrm{pH}$ 5.5-6.0 & 0 & 90 & 3.68 & .27 & 1.67 & .69 & .46 & 121 & 1240 & 22 \\
\hline 10 & To $\mathrm{pH} 5.5-6.0$ & 0 & 179 & 3.65 & .21 & 1.18 & .44 & .29 & 77 & 955 & 15 \\
\hline 11 & To $\mathrm{pH} 5.5-6.0$ & 359 & 22 & 3.68 & .28 & 1.70 & .56 & .31 & 102 & 1175 & 18 \\
\hline
\end{tabular}

${ }^{1}$ Blanket application: $191 \mathrm{~kg} / \mathrm{ha} \mathrm{N}, 112 \mathrm{~kg} / \mathrm{ha} \mathrm{K}$ and $56 \mathrm{~kg} / \mathrm{ha} \mathrm{Mg}$.

apart at a distance of $2.5 \mathrm{~cm}$ between plants for a population of approximately 860,000 plants/ha.

The third fully developed trifoliate leaves were sampled for tissue analysis at early flowering, 42 days after sowing. Subplots of $1.83 \times 7.62$ $\mathrm{m}$ were selected from the four middle rows of each plot for yield calculations. A field-wide grain yield average of $3698 \mathrm{~kg} / \mathrm{ha}$ (55 bu/acre) was obtained, but there were no statistical differences among treatments. This yield was almost twice that of the average commercial 1973 U.S. yield and demonstrated the potential for growing soybeans on Ultisols of the humid tropics.

Soil samples taken after harvesting revealed that the amount of $\mathrm{P}$ extracted by the Bray No. 2 method dropped about $40 \%$ during the growth of this crop. All but the treatments with $1120 \mathrm{~kg} / \mathrm{ha} \mathrm{P}$ were below $20 \mathrm{p} / \mathrm{m}$, which is considered low for Alabama soils.

After only 2 years in which four crops were grown, the residual effects of $359 \mathrm{~kg} / \mathrm{ha}$ P raised the extractable P levels only a few $\mathrm{p} / \mathrm{m}$. 
FIFTH CROP: CORN, FUNK G-795 W (WHITE KERNEL)

The fifth crop (third corn crop) was planted under conditions identical as those of the two previous corn crops.

The plants in most treatments grew quite erratically during the first 2 months. There was a large variation in plant height within most plots, and the smaller plants showed P deficiency symptoms. It was assumed that plant height variability was a function of whether or not the plant roots had encountered areas of higher soil $\mathrm{P}$ concentrations. This variability continued until harvest; thus, only large differences between treatments were significant. However, the results indicated that the P fertilizer applied in the fall of 1971 had only moderate residual effects on the grain yield of this crop planted in the fall (November 23 of 1973). The largest grain yields were obtained from the treatment receiving $179 \mathrm{~kg} / \mathrm{ha}$ of banded $\mathrm{P}$ on each individual crop. The yield of $5,813 \mathrm{~kg} / \mathrm{ha}$ of corn grain in the $179 \mathrm{~kg} / \mathrm{ha}$ banded $\mathrm{P}$ treatment was significantly higher than the yields from all other treatments, including the $4,206 \mathrm{~kg} / \mathrm{ha}$ obtained on the limed, $1,120 \mathrm{~kg} / \mathrm{ha} 1971$ broadcast P treatment. Soil analyses (table 3) also indicated that available $\mathrm{P}$ content in the broadcast treatments had dropped sharply during the past 3 years. Thus, it appeared that fertilizer $\mathrm{P}$ was probably being fixed quite rapidly in this soil, and banded applications of moderate quantities of fertilizer $\mathrm{P}$ for each crop were more efficient in increasing yields than large broadcast applications made every few years.

\section{SIXTH CROP: CORN, FUNKS G-795 W}

This experiment was planted May 8, 1974. Severe drought symptoms appeared during the first 3 months of growth, especially at tasseling and there was a large variation in plant population. The northern leaf blight affected the crop considerably although some control was obtained with weekly applications of a fungicide.

Again, banded P appeared to be more efficient than 1971 broadcast, residual $\mathrm{P}$. The mean grain yield for broadcast treatments (table 4, treatments 2-6) was of the order of $2913 \mathrm{~kg} / \mathrm{ha}$; those for the banded P treatments (7-10), 3,315 kg/ha.

The most remarkable result from this experiment was that, in spite of the deficient soil $\mathrm{P}$ content in all the treatments, except in the limed and unlimed $1120 \mathrm{~kg} \mathrm{P} / \mathrm{ha}$, no visual deficiencies were observed in the corn plants. The zero $\mathrm{P}$ plots produced around 2,500 $\mathrm{kg}$ of grain, being significantly outyielded only by the limed, $1120 \mathrm{~kg} / \mathrm{ha}$, and by the 45 and $179 \mathrm{~kg} / \mathrm{h}$ a banded $\mathrm{P}$ treatments. The overall mean from the experimental field was $3,042 \mathrm{~kg} / \mathrm{ha}$ of grain. This is not substantially lower than the mean for many of the individual treatments. Thus, it appears that either there was sufficient $\mathrm{P}$ available gradually by mineralization of organic 
materials or the Funk's G-795 W hybrid is an efficient feeder on relatively unextractable soil P.

\section{SEVENTH CROP: CORN, P-X-306-B}

No yield data was obtained since on January 16, 1975 the experiment was totally ruined by cattle from an adjoining farm. However, leaf samples were taken at silking before the damage was done. Leaf analyses (table 6) did not reveal much variation in $\mathrm{P}$ content. In fact, $\mathrm{P}$ levels in all treatments were relatively low $(0.16-0.24 \%$ sufficiency as reported by Jones). ${ }^{7}$ No visual $\mathrm{P}$ deficiencies were observed in the leaves.

Analysis of soil samples taken after the experiment was discarded,

TABLE 6.-Percent $P$ in corn ear leaf at silking (mean of 5 replications) seventh crop (fifth corn crop).

\begin{tabular}{|c|c|c|c|c|}
\hline & Lime & Broadcast P & Banded $\mathrm{P}$ & $\mathrm{P}$ \\
\hline & & \multicolumn{2}{|c|}{$\mathrm{Kg} / \mathrm{ha}$} & $\%$ \\
\hline 1. & 0 & 1120 & - & .25 \\
\hline 2. & To pH $5.5-6.0$ & 0 & - & .20 \\
\hline 3. & To $\mathrm{pH}$ 5.5-6.0 & 90 & - & .21 \\
\hline 4. & To pH 5.5-6.0 & 179 & - & .23 \\
\hline 5. & To $\mathrm{pH} 5.5-6.0$ & 359 & - & .21 \\
\hline 6. & To pH. 5.5-6.0 & 1120 & - & .23 \\
\hline 7. & To $\mathrm{pH} 5.5-6.0$ & 0 & 22 & .21 \\
\hline 8. & To pH 5.5-6.0 & 0 & 45 & .23 \\
\hline 9. & To $\mathrm{pH} 5.5-6.0$ & 0 & 90 & .24 \\
\hline 10. & To $\mathrm{pH} 5.5-6.0$ & 0 & 179 & .24 \\
\hline 11. & To $\mathrm{pH} 5.5-6.0$ & 359 & 22 & .25 \\
\hline
\end{tabular}

harvesting from the $\mathrm{P}$ broadcast plots, revealed that in all treatments values were below $20 \mathrm{p} / \mathrm{m}$ and, therefore, apparently deficient in available P.

EIGHTH CROP: CORN, P-X-306-B

This crop was planted June 20, 1975. Results from leaf analysis of samples taken at silking revealed relatively high $\mathrm{P}$ concentrations in all treatments (table 7). Sufficiency levels for P, established by the Ohio Plant Analysis Laboratory (7), ranged between 0.25 to 0.40 . In this case, the control (treatment 2) showed a $\mathrm{P}$ content similar to that of the higher fertilizer $\mathrm{P}$ treatments (treatments 1 and 4). Magnesium levels were somewhat low (sufficiency ranges between 0.21-0.40\%); B levels were also low (low, between $3-5 \mathrm{p} / \mathrm{m}$ ). In general, $\mathrm{Mn}$ levels were high (between 151-200 p/m), especially in treatment 1 with the highest amount of fertilizer $\mathrm{P}$ and no lime. These results are apparently in conflict with

\footnotetext{
${ }^{7}$ Benton, J. Jones, Jr., Soil testing and plant analysis, Part II, Soil Sc. Soc. Amer., 1967.
} 
TABle 7.-Leaf nutrient content of corn, Pioneer X-306 B at silking, Cidra, September 1975 (mean of 5 replications)

\begin{tabular}{|c|c|c|c|c|c|c|c|c|c|c|c|c|c|c|}
\hline Treatment & Lime & $\begin{array}{l}\text { Broadcast } \\
\text { P }\end{array}$ & $\begin{array}{l}\text { Banded } \\
\text { each yr. }\end{array}$ & $\mathrm{N}$ & $\mathrm{P}$ & $\mathrm{K}$ & $\mathrm{Ca}$ & $\mathrm{Mg}$ & $\mathrm{Mn}$ & $\mathrm{Fe}$ & B & $\mathrm{Cu}$ & $\mathrm{Zn}$ & $\mathrm{Al}$ \\
\hline & & $K g / h a$ & $\mathrm{Kg} / \mathrm{ha}$ & & & & $\%$ & & & & \multicolumn{4}{|c|}{$p / m$} \\
\hline 1 & 0 & 1121 & 0 & 3.76 & .43 & 2.11 & .34 & .16 & 387 & 149 & 5 & 14 & 29 & 67 \\
\hline 2 limed & To $\mathrm{pH} 5.5-6.0^{1}$ & 0 & 0 & 3.00 & .42 & 2.53 & .34 & .13 & 153 & 167 & 5 & 14 & 23 & 75 \\
\hline 3 & To $\mathrm{pH} 5.5-6.0^{1}$ & 90 & 0 & 2.51 & .38 & 2.34 & .31 & .13 & 165 & 157 & 4 & 12 & 23 & 75 \\
\hline 4 & To $\mathrm{pH} 5.5-6.0^{1}$ & 179 & 0 & 2.96 & .43 & 2.78 & .35 & .14 & 250 & 156 & 4 & 11 & 25 & 66 \\
\hline 5 & To $\mathrm{pH} 5.5-6.0^{1}$ & 359 & 0 & 3.12 & .46 & 2.29 & .34 & .11 & 155 & 156 & 4 & 9 & 25 & 58 \\
\hline 6 & To $\mathrm{pH} 5.5-6.0^{1}$ & 1121 & 0 & 3.19 & .50 & 2.34 & .43 & .15 & 191 & 154 & 5 & 8 & 24 & 66 \\
\hline 7 & To $\mathrm{pH} 5.5-6.0^{1}$ & 0 & 22 & 2.41 & .40 & 2.36 & .34 & .13 & 176 & 153 & 5 & 8 & 24 & 75 \\
\hline 8 & To $\mathrm{pH} 5.5-6.0^{1}$ & 0 & 45 & 2.96 & .43 & 2.52 & .47 & .14 & 187 & 161 & 6 & 8 & 27 & 78 \\
\hline 9 & To $\mathrm{pH} 5.5-6.0^{1}$ & 0 & 90 & 2.89 & .49 & 2.24 & .46 & .14 & 216 & 193 & 5 & 9 & 25 & 82 \\
\hline 10 & To $\mathrm{pH} 5.5-6.0^{1}$ & 0 & 179 & 3.00 & .43 & 2.57 & .44 & .14 & 200 & 164 & 6 & 7 & 21 & 86 \\
\hline 11 & To $\mathrm{pH} 5.5-6.0^{1}$ & 359 & 22 & 2.32 & .43 & 2.42 & .40 & .11 & 173 & 156 & 5 & 10 & 23 & 75 \\
\hline
\end{tabular}

${ }^{1}$ A total of 16.8 metric tons/ha (7 1/2 tons/a) of lime had been applied prior to planting the soybean experiment (Expt. No. 4 ); 7.8 tons before planting the first corn crop and 9 tons after harvesting the first corn crop and 9 tons after harvesting the first corn experiment, except in treatment 1. 
those obtained from crop 7. However, the $\mathrm{P}$ may have been mineralized more rapidly during the summer months and thus become readily available to plants (25).

A mean grain yield of $3,684 \mathrm{~kg} / \mathrm{ha}$ was obtained. The results for grain yield are consistant with those obtained from the previous experiment. In general, small amounts of banded $\mathrm{P}$ at planting resulted in higher yields than large amounts of broadcast $P$ applied every few years. Banded $\mathrm{P}$ applied at the rate of $22 \mathrm{~kg} / \mathrm{ha}$ outyielded almost all of the broadcast treatments (table 4). The lowest yield, $2997 \mathrm{~kg} / \mathrm{ha}$, was recorded from the unlimed $1121 \mathrm{~kg} / \mathrm{ha}$ of $\mathrm{P}$ treatment. As in the previous experiment, analysis of soil samples, taken after harvesting in the broadcast treatments, revealed very low and deficient $\mathrm{P}$ content, except for the two high $\mathrm{P}$ treatments (treatments 5 and 6 ) where $\mathrm{P}$ levels were more than twice as high as the others (table 3 ).

\section{NINTH CROP: FIELD BEANS, CV BONITA}

A field bean experiment with local cultivar Bonita was planted April 8, 1976. Plots consisted of 4 rows each $61 \mathrm{~cm}$ apart and $3.0 \mathrm{~m}$ in length. Two additional rows were added at both sides of the plots as borders following the same interrow distance. Distance between plants in the row was 7.6 $\mathrm{cm}$ for a density of 172,149 plants/ha. The experiment was harvested July 9, 1976.

The bean rust (Uromyces phaseoli) caused premature leaf senescense from peak flowering to the pod filling stages and reduced yields. As in the two previous experiments, it appears that banded applications of moderate amounts of $\mathrm{P}$ were more effective than larger amounts of broadcast $\mathrm{P}$ every few years. The highest bean yields were obtained with $22 \mathrm{~kg} / \mathrm{ha}$ of banded P. Yields from plots where banded rates of 22 and $45 \mathrm{~kg} / \mathrm{ha}$ of $\mathrm{P}$ were applied were significantly larger in 4 out of 6 of the broadcast $\mathrm{P}$ treatments (table 4).

Soil test values indicated a low level of available $\mathrm{P}$ in the soil.

\section{TENTH CROP: FIELD BEAN, CV BONITA}

A second field bean experiment was originally planted July 11, 1977 but was totally replanted in August 1977 following the same procedures as those described for the preceding experiment. It was harvested October 19, 1977.

Observations made 2 weeks after replanting revealed that plants from all the broadcast residual $\mathrm{P}$ treatments were smaller than plants from the banded $\mathrm{P}$ treatments. The former were of a lighter green color than the latter. However, this difference in color disappeared later and no height differences were observed a month later, except in the zero-P plots where plants remained stunted with small leaves. Surprisingly, these 
plots recovered quickly 2 weeks afterwards, showing as good vigor and color as those from the other treatments.

The experiment was harvested at an early stage because of the considerably high humidity, which caused plant rot. Some plots located in low parts of the field were flooded occasionally during heavy rainfall. Such plots were nearly devoid of plants at harvest. Total rainfall recorded was $500 \mathrm{~mm}$ distributed as follows: August, $232 \mathrm{~mm}$; September, $187 \mathrm{~mm}$ and October, $81 \mathrm{~mm}$.

No grain yield was recorded because of high disease and insect incidence which resulted in a crop failure. This might be due to the fact that the beans were planted off-reason. Instead, plants were harvested for stover yield measurements and $\mathrm{P}$ content and total $\mathrm{P}$ uptake determinations. No significant differences were apparent as to stover yields.

Results from analysis of soil samples, taken after harvesting, revealed very low and deficient available $\mathrm{P}$ content in the soil (table 3 ). In some cases, as in treatments 2,3 and 4 the $P$ content was $1 / 2$ the level measured in the previous experiment.

\section{OVERALL INTERPRETATION OF DATA}

Yields varied considerably among treatments, even though soils were reasonably uniform. Other factors, such as disease affecting certain crops, undoubtedly contributed to the variability. In the first crop, response to $\mathrm{P}$ was significant, with some advantage for the banded $\mathrm{P}$ treatments. Yields from $90 \mathrm{~kg} \mathrm{P}$ banded were as high as from $1120 \mathrm{~kg} \mathrm{P}$ broadcast ahead of planting. In the second crop, treatments had no effect on corn yields. In the third crop (rice) there was no response to $\mathrm{P}$ applications, yields were low, and disease reduced yields on the experiment. The yields of soybeans (crop 4) were high, with no differences between treatments. From the fifth though the eighth crop, yields from the banded $P$ treatments ( $\mathrm{P}$ applied to each crop), were superior to those of the broadcast treatments. However, increases in yield from banded treatments were modest compared with the P control on the latter crops. Except for the first corn crop, throughout the course of the experiment, the broadcast treatments were not greatly different from the control.

It must be pointed out that the soil at Cidra had been intensively cropped to sugarcane and tobacco and received heavy dressings of $\mathrm{P}$ fertilizers. The lack of response to $\mathrm{P}$ in this soil probably illustrates the high residual effect of fertilizer $\mathrm{P}$ at this site.

Two important processes affecting $\mathrm{P}$ availability must not be overlooked; fixation and organic P mineralization. Under field conditions, soil P dropped sharply on the Cidra broadcast plots after 3 years of cropping. This could perhaps be attributable to fixation. Organic P mineralization also appears to be rather important in the highly weathered soils of the 
humid tropics. Apparently, $\mathbf{P}$ is mineralized more readily during the summer months (25). In a series of experiments conducted in 1978 with various soils including the Torres at Cidra, data revealed that the greatest amount of mineralized $\mathrm{P}$ was obtained from the Torres clay from Cidra (25).

\section{RESUMEN}

En una secuencia de diez cosechas en un suelo de la serie Torres (Ultisol) se midieron respuestas variables a las aplicaciones de fósforo. El arroz y las habichuelas soyas no respondieron a las aplicaciones de P. En tres de seis cosechas de maíz y en dos de habichuelas secas se obtuvieron respuestas a aplicaciones de $\mathrm{P}$ cuando se hicieron en franjas. En la primera cosecha de maíz, casi se alcanzaron rendimientos máximos con aplicaciones de $90 \mathrm{~kg} / \mathrm{ha}$ de $\mathrm{P}$ en franjas y con $359 \mathrm{~kg} / \mathrm{ha}$ de $\mathrm{P}$ a voleo. El efecto residual en cosechas subsiguientes de aplicaciones grandes de $\mathrm{P}$ a voleo fue casi nulo. Bajo condiciones de campo, el contenido de $\mathrm{P}$ que se puede extraer del suelo bajó drásticamente en las parcelas que recibieron $\mathrm{P}$ a voleo, después de 3 años de aplicado. Esto quizás pueda atribuirse a la fijación del $\mathrm{P}$.

La mineralización del $\mathrm{P}$ orgánico parece ser bastante importante en los suelos altamente intemperizados de los trópicos húmedos. Aparentemente el P se mineraliza con mayor rapidez durante los meses de verano.

\section{LITERATURE CITED}

1. Annual Report of the Insular Experiment Station of the Department of Agriculture and Labor of Puerto Rico. Fiscal year 1943-44.

2. Abruña, F. and Figarella, J., 1957. Some effects of calcium and phosphorus fertilization on the yield and composition of a tropical Kudzu grass pasture, J. Agri. Univ. P.R. 41 (4):231-5.

3. Vicente, J. and Silva, S., 1959. The effect of different fertility levels on yields of intensively managed coffee in Puerto Rico, J. Agri. Univ. P.R. 43 (3):141-6.

4. - Vicente Chandler, J., Becerra, L. A., and Bosque-Lugo, R., 1965. Effects of liming and fertilization on yields and foliar composition of high-yielding sun-grown coffee in Puerto Rico, J. Agri. Univ. P.R. 49 (4):413-7.

5. Beinroth, F. H. and Jordán-Molero, J. E., 1971. Phosphorus experiments, A report to Cornell Univ., Ithaca, N. Y.

6. Benton Jones, J., Jr., 1967. Interpretation of plant analysis for several agronomic crops, from Soil Testing and Plant Analysis part II, Soil Sci. Soc. Am., pp 49-58.

7. Bonnet, J. A., Tirado Sulsona, P., and Abruña, F., 1947. Effect of lime-phosphorus and green manure on sweet potatoes and corn grown in acid soils, J. Agri. Univ. P.R. 31 (4):303-21.

8. - Riera A., and Lugo-López, M. A., 1958. Lack of response of old coffee trees grown in Alonso clay to lime and phosphatic fertilization, J. Agri. Univ. P.R. 42 (3):161-7.

9. - 1963. Response of eighteen consecutive sugarcane crops to NPK in Puerto Rico, Univ. P.R. Agri. Exp. Stn. Tech. Pap. 38.

10. Del Valle, Jr., R., Scott, T. W., Rodríguez, J., and Lugo-López, M. A., 1978. Response 
of plantings to banded and broadcast $\mathrm{N}$ and $\mathrm{P}$ applications at planting and to residual P on an Ultisol, J. Agri. Univ. P.R. 62 (1):29-8.

11. Estación Experimental Agrícola, Informe Anual 1975-76.

12. Estación Experimental Agrícola, Informe Anual 1976-77.

13. Estación Experimental Agrícola, Informe Anual 1977-78.

14. Estación Experimental Agrícola, Informe Anual 1954-55.

15. Figarella, J., Vicente Chandler, J., Silva, S., and Caro Costas, R., 1964. Effects of phosphorus fertilization on productivity of intensively managed grasses under humid tropical conditions in Puerto Rico, J. Agri. Univ. P.R. 48 (3):236-42.

16. Fox, R., Badillo, J., Del Valle, R., and Scott, T. W., 1976. Response of corn to phosphorus fertilizer in greenhouse, sunken drums, and field experiments, J. Agri. Univ. P.R. 60 (1): 88-2.

17. Kamprath, E. J., 1967. Phosphorus. In: A review of soils research in Tropical Latin America, (P. A. Sánchez, Ed), N.C. Agri. Exp. Stn. Bul. 219.

18. Landrau, P., Jr. and Samuels, G., 1951. The effect of fertilizers on the yield and quality of sweet potatoes, J. Agri. Univ. P.R. 35 (2):71-87.

19. Muñiz Torres, O., 1979. Efecto de diferentes niveles de nitrógeno y fósforo en la producción y calidad de maíz dulce Zea mays var. saccharata, en un Oxisol arcilloso de Isabela y un Vertisol arcilloso de Lajas, Puerto Rico, Tesis M.S., Recinto Universitario de Mayagüez.

20. Samuels, G., and Capó, B., 1956. Research with sugarcane fertilizers in Puerto Rico, 1910-54, Agri. Exp. Stn. Tech. Pap. 16.

21. - Landrau, P., Jr., and Alers-Alers, S., 1956. Influence of phosphate fertilizers on pineapple yields, J. Agri. Univ, P.R. 40 (4):218-3.

22. - 1966. Pineapple fertilizer research in Puerto Rico 1955-66. 4th Ann. Meet. Caribbean Food Crops Soc. July 25, August 1, p. 100-7.

23. Spain, G. L., 1971. Annual report of research projects, Agri. Exp. Stn. Univ. P.R.

24. - 1973. Annual report of research project, Agri. Exp. Stn. Univ. P.R.

25. Wahab, A. H., Lugo-López, M. A., and Scott, T. W., 1980. Exploratory tests on mineralization of organic phosphorus in an Ultisol J. Agri. Univ. P.R. Submitted for publication. 